Western Faunt (Lawrence, Kansas: The Regents Press of Kansas, 1981). I thank the Society's Director of Archives for detaching (on 16 October 1980) the postcard from the loose leaf to which it had been only partially pasted.

\title{
WHITMAN IN THE SOUTHERN LITERARY MESSENGER
}

Walt Whitman did not go unnoticed in The Southern Literary Messenger. In three different issues, the "Editor's Table" section of the magazine once edited by Edgar Allan Poe made Whitman the subject of ridicule. ${ }^{1}$ The July 1860 number carefully reprinted Whitman's "Longings for Home" (later titled "O Magnet South") from the 1860 edition of Leaves of Grass. This, apparently, was the poem's second printing. ${ }^{2}$ But the action was not a friendly one. George W. Bagby, the gifted humorist, raconteur, and staunch Southern patriot who assumed the editorial helm of the Messenger in June 1860, used his introductory comments to lash out against Whitman, Emerson (note the allusion to Representative Men), and all Northern literature:

The pantheism of Theodore Parker and Ralph Waldo Emerson, pervades and pollutes the entire literature of the North. It is nowhere more apparent than in that clumsy romance, "The Marble Faun." It culminates in the spasmodic idiocy of Walt Whitman. The smart scribblers who compose the better part of the Northern literati, are all becoming infected with the new leprosy - Whitmansy. This latest "representative man" of the North has his imitators by the hundred, his admirers by the thousand, and an organ-the slang-whanging paper called The Saturday Press. A specimen of the twangling-jack style of Whitman is given below. Take a pair of frog-legs, put a tongue to every toe of both legs, and place the legs under a galvanic battery -and you have the utterings of Whitman. In the following slosh [i.e., "Longings for Home"], Whitman says he "grew up" in Virginia. We should feel mean if this statement were anything else than a Whitmaniacal license, accent on the first vowel in license. Here is the sample of his obnubilate, incoherent, convulsive flub-drub.

When a reader protested that "Longings for Home" was a pretty good poem, Dr. Bagby demolished the upstart, in the August 1960 number, in a style reminiscent of Mark Twain's lampoons of rambunctious antebellum journalism:

"The Writer," writing from New York, tells us that he "liked Walt Whitman's 'Longings for Home' very much." We appreciate the information. He tells us further, that "Ossian's poetry is something in the style of Whitman's." Only remotely and feebly, we consider. The Bible, also, is "something in the style of the Book of Mormon." Also, paste is "something in the style" of the diamond. Also, the goose is "something in the style" of the swan. Also, "The Writer" is "something in the style" of the goose, and we doubt not the imitation is a close and successful one....

In the January 1862 number, the "Editor's Table" printed a 68-line parody of Whitman's verse entitled "The War"; it was prefaced by Dr. Bagby's remarks, as follows: 
Here is not only the best imitation, by long odds, of Walt Whitman, the b'hoy-poet and representative man of Yankeedom, which we ever saw, but an excellent bit of sarcasm besides. The author is the same who wrote that capital parody on Southey's "On to Moscow," entitled "On to Richmond."

But the parody itself, written in the days when the Southern cause seemed triumphant, is lame and inept. Except for its mockery of Whitman's parallelism and "spasmodic" style, some gratuitous French, and a reference to Sesostris, the parody's chief interest is historical. It pictures Whitman as a drunken Northern jingoist, ranting to all who will listen (in the darkest days of the Northern cause) that the South is all but defeated; that the disastrous battles of Bull Run, Manassas, and Centreville were really Northern victories: "And didn't we celebrate the victory in a pundy branch on the Avenue? / I should say so." Ultimately, incoherent with drink, he passes out.

That Whitman, who did not leave for Washington for almost a year after the parody appeared, should be mocked as a bellicose spokesman of Northern aggression was not altogether without provocation on his part. Only two months earlier, on 28 September 1861, both Harper's Weekly and the New York New Leader had published his stirring call to arms, "Beat! Beat! Drums!" Ironically, this was Whitman's only war poem to be published before the appearance of Drum-Taps in $1865 .^{3}$ The Southern Literary Messenger's virulent response shows how effective a war poem Whitman had composed.

California State University, Long Beach

HAROLD ASPIZ

\section{NOTES}

1 [George William Bagby,] "Editor's Table," The Southern Literary Messenger, 31 (July 1860), 74-75; 31 (August 1860), 155; 34 (January 1862), 72-73. These items are not listed in Scott Giantvalley, Walt Whitman, 1838-1939: A Reference Guide (Boston: G. K. Hall \& Co., 1981).

2 Leaves of Grass, Comprehensive Reader's Edition, edited by Harold W. Blodgett and Sculley Bradley (New York: New York University Press, 1965), pp. 472-474n.

3 Leaves of Grass, p. 283n. Two Drum-Taps poems had appeared in the 1860 edition: "Not the Pilot" (Leaves of Grass, p. 308) as a "Debris" poem; "Over the Carnage Rose Prophetic a Voice" (Leaves of Grass, pp. 315-316) as "Calamus, No. 5," a chant of brotherhood, not war.

\section{WALT WHITMAN'S JOURNALISM: MISSING FILES}

Despite extensive research, aided by an American Philosophical Society grant, I have failed to locate files or issues of some newspapers which Whitman either wrote for or edited, newspapers needed to help complete Walt Whitman, The fournalism, volumes in The Collected Writings of Walt Whitman (New York University Press).

Most needed are the following newspapers:

1. Long Island Patriot. 1831-1832. 